DOI 10.37882/2500-3682.2021.03.12

\title{
СОЦИАЛЬНО-ПСИХОЛОГИЧЕСКИЕ АСПЕКТЫ ДЕСТРУКТИВНОГО ВОЗДЕЙСТВИЯ НА ЛИЧНОСТЬ
}

\section{SOCIO-PSYCHOLOGICAL ASPECTS OF THE DESTRUCTIVE IMPACT ON THE INDIVIDUAL}

V. Melnikov

Summary: The article is devoted to the socio-psychological aspects of the impact of antisocial groups and destructive associations on young people. It is noted that the majority of destructive formations, terrorist, extremist and radical groups are created to destabilize the socio-political situation in the state, pursue destructive goals, seek to use psychotechnologies of intimidation, violence and manipulation of the individual. The assessment of modern phenomena of destructiveness, procedural components, methods, and psychotechnics of manipulating the consciousness of an individual in a group is given. The author emphasizes the originality of the use of destructive applied practices of «communion», «recruitment» of neophytes, ways of reforming consciousness, drawn from pseudoreligious cults, criminal activities and subcultures, etc. In the summary, a system of preventive measures to counteract the penetration of destructive phenomena into the youth environment is proposed.

Keywords: consciousness, personality, destruction, deviation, addiction, religious cult, criminal subculture, mental violence, manipulation, psychotechnology of influence, consciousness reform, communion syndrome, «recruitment» techniques, prevention, frustration tolerance.

Д

ля современной России многие виды угроз происходят на фоне обострения и распространения политического, этнического, религиозного эксма, идеологии терроризма и радикализма.

Наука давно изучает феномены социально-психологической общности с практической ориентацией на асоциальные группы и объединениями деструктивной направленности. Различные стороны природы личности, ее формирования отклоняющегося поведения составляют предмет дискуссии многих отечественных ученых, таких как Б.Г. Ананьев, А.Н. Леонтьев, Б.Ф. Ломов, С.Л. Рубинштейн, К.К. Платонов, А.Р. Ратинов, А.В. Дулов, В.Ф. Пирожков, А.Э. Жалинский, В.В. Лунеев, В.С. Овчинский и др.

По оценкам исследователей в мире насчитывается десятки тысяч разного толка идейных, тоталитарных сект, деструктивных культов и харизматических групп. Сегодня важно выявить основные идеи, сопоставить и определить значение тех явлений и процессов, которые происходят в асоциальных группах и объединениях деструктивной направленности, в т.ч. террористических и
Мельников Владимир Михайлович

К.nсх.н., доцент, Бурятский государственный университет melnikov-baikal@yandex.ru

Аннотация: Статья посвящена социально-психологическим аспектам воздействия асоциальных групп и объединений деструктивной направленности на молодежь. Отмечается, что большинство деструктивных образований, террористических, экстремистских и радикально настроенных групп создаются для дестабилизации общественно-политической ситуации в государстве, преследуют разрушительные цели, стремятся использовать психотехнологии устрашения, насилия и манипулирования личностью. Дается оценка современным явлениям деструктивности, процедурным компонентам, методам, психотехникам манипулирования сознанием личности в группе. Подчеркивается неординарность применения деструктивных прикладных практик «приобщения», «вербовки» неофитов, способов реформирования сознания, почерпнутых из псевдорелигиозных культов, криминальной деятельности и субкультуры и др. В обобщении предлагается система профилактических мер по противодействию проникновения деструктивных явлений в молодежную среду.

Ключевые слова: сознание, личность, деструкция, девиация, аддикция, религиозный культ, криминальная субкультура, психическое насилие, манипуляция, психотехнология воздействия, реформирование сознания, синдром приобщения, приемы «вербовки», профилактика, фрустрационная толерантность.

экстремистских группах, тоталитарных религиозных сектах, деструктивных интернет-сообществах, группах наркоманов, уличных хулиганов, спортивных и иного плана фанатов и др.

В деятельность по дестабилизации внутриполитической и социальной ситуации активно вовлекается молодежь, именно она является наиболее уязвимым объектом воздействия средств идеологического информационно-психологического и культурного противоборства.[12]

Не каждый вид асоциальной деструктивной группы обладает высоким уровнем организованности, сплоченностью, взаимной эмоциональной привлекательностью. Однако некоторые из них созданы по типу высокоорганизованных (полувоенных) организаций, ориентированных на ситуацию конфликта и достижение цели в направлении политической, террористической экстремистской, религиозно-националистической, криминальной деятельности. 
В современной психологической науке понятийный аппарат, характеризующий деструктивное поведение сформирован не в полной мере. Чаще можно встретить понятие «агрессия, «деструкция», «деструктивность». Скорее всего, это связано процессом развития, последовательной сменой оснований дифференциации и интеграции, которая определяет смену стадии развития и поведения членов той или иной общности.

В научном плане на анормальность деструкции указывал 3. Фрейд, характеризуя ее как врожденное базисное влечение к разрушению в поведении, в т.ч. результат отрицательного отношения индивида к самому себе. К. Лоренс рассматривал деструктивность через агрессивность человека. Э. Фромм усматривал связь между разрушающим поведением и нереализованным потенциалом человека. В современных исследованиях ученые указывают на разные формы интраперсональных, интерперсональных и метаперсональных вариантов поведения, не сводимых к агрессии или насилию, но приводящих к разрушению в группах. [10]

Деструктивные религиозные, политические и террористические группы, во-многом, схожи с харизматической группой. Тем не менее, они активно заявляют о своей приверженности идеям, посредством возбуждения ненависти, вражды, применяя инструменты психического давления, насилия и манипуляции. Ярким примером тому программы и «ячейки» современной информационно-телекоммуникационные сети, включая «Интернет», как средство коммуникации экстремистских и террористических организаций. Большой разницы в идеологии и ритуальном поведении между деструктивными объединениями и организациями нет. Они сходны предметом деятельности, процедурными компонентами, приемы вступления неофитов в группу, требованием к соблюдению правил и исполнению обязательств. Внутри сети лидеры групп используют открытую и символическую тактику сохранения структуры с жестким соблюдением дисциплины. Однако, реальная природа их власти располагается на внутригрупповом уровне психического и морального подавления личности с элементами манипуляции. Это достаточно сложный и универсальный вид психологического воздействия на человека с целью «одностороннего выигрыша посредством скрытого побуждения другого к совершению определенных действий». [3]

Криминальный мир также располагает особым арсеналом деструктивного воздействия на людей, почерпнутым из истории своего существования и субкультуры. Воздействие на избранную личность предусматривает тщательное изучение, отбор, воспитание с привитием традиций и норм криминальной идеологии и культуры. Воспитание предусматривает знание «воровских законов», порядков, неформальных правил поведения, способов ведения психологической войны и контрпропаганды. В исследованиях криминологов отмечается, вероятность принятия асоциальных ценностей определяется степенью изоляции от обычных групп, частотой и продолжительностью контактов с представителями криминальной субкультуры, наличием к ним любви и уважения. [7]

Сторонники теории криминальной субкультуры, объясняют ее происхождение в терминах теории напряжения, склонностью некоторых группировок к определенным ценностям доминирующей культуры. [4] Вербальное общение - один из внешних векторов преступного поведения. Во внутренней деятельности его проявление связано с психологической защитой личности с отождествлением и подавлением агрессора.

В науке понятия «культ» и «секта» являются идентичными. К.Г. Юнг писал, в истории человечества религиозные представления обладают величайшей эмоциональностью и внушаемой силой.[9] В условиях идеологического плюрализма, растущий интерес к религиозности вызывает естественную потребность в свободном духовном самоопределении, а также активную духовную экспансию псевдорелигиозных организацийсект, стремящихся заменить вероучения новейшей неординарной прикладной практикой. [1]

В перечень психологических методов воздействия деструктивных культов и тоталитарных сект входит особая система, конечной целью которой является формирование зависимости. Система удержания новичка связана с предоставлением временных уступок, контактов с «посвященным» и с группой, приемами контроля сознания с позитивным подкреплением. В итоге, культовый контроль сознания постепенно формирует у личности импульсивное желание приобрести религиозную «истину» и находится среди себе подобных.

Молодежь в силу возрастных особенностей часто занята поисками героев и идеалов, установлением новых каналов связи. Однако, в силу разных причин потребности перестают удовлетворять личность, что приводит когнитивному диссонансу, в некоторых случаях к аддикции с оппозиционно-вызывающими представлениями о жизни. Недостаточная сформированность функций психического контроля, эмоциональность, внутренние противоречия повышаю уровень конфликтности и приводят протестным формам поведения. Подобные «риски» напрямую связаны со многими случаями совершения непоправимых ошибок в жизненных ситуаций.

Мы убеждены, на каждом этапе своего развития деструктивные сообщества искали и применяли различные способы воздействия на человека. В истории криминологии и юридической психологии хорошо известна 
личность Робин Гуда. Часть его «лесного братства» составляли простые люди, которые были «куплены» и за определенную плату поставляли всю необходимую информацию.

Для деструктивных структур особую ценность всегда представляли компетентные подготовленные проповедники, пропагандисты и эмиссары. С одной стороны, они были призваны вселять в людей надежду, «оживлять веру», а на деле это были «ловцы душ», создающие паству из «новообращенных». В конечном счете, выбранные ими «жертвы» должны были пойти в направлении изоляции социальных контактов, получить поддержку и удовольствие от интеллектуальных контактов с «родственными душами». Таких людей привлекает эстетика, духовные знания и достижения, образы, мистицизм, эзотерика и оккультизм. В других случаях, под воздействием психологических манипуляций («сеансов лжи») происходит «реформирование сознания».

Наиболее известными признаками «приобщения» и «вербовки» является «игра на комплексах и страхах», «предложение в помощи», «просьба об услуге», «манипуляция на уровне эмоций», «давление на характер» и «угроза». Психологическая тактика втягивания в группу объединяет приемы «заражение эмоциональным состоянием», «внушение», «убеждением примером и доводами». «Вербовщики» активно применяют психологическую типологию деления людей на «мыслителей», «чувствующих», «деятельных» и «верующих», а также частные разработки управления человеком. Под каждый тип личности создается программа втягивания и психологической «пристройки», учитывающая разные аспекты и проблемы жизни. В ходе обработки «жертве» навязывается роль «не признанных», «бесполезных слабаков» у которых имеется шанс что-то предпринять.

На начальном этапе «вербовки» происходит безобидная встреча, знакомство с приглашением продолжить переписку через социальные сети интернета. Приветствуется совместное время отдыха, путешествия, посещение культурных, религиозных учреждений, и других мест с массовым пребыванием людей. Существует практика передачи «жертвы» более опытному «вербовщику». В случае протеста или отказа «вербовщики» используют продуманные способы контраргументации. На примере, Е. Карауловой можно судить, что она жесткую «прочистку сознания» под угрозой жизни с требованием принять другую реальность, ценности и установки и др.

В работе «вербовщиков» особое значение имеет организация работы с молодежной группой. В данном случае учитываются гендерные, половозрастные, национальные особенности, уровень развития, статус и проблемы социального окружения, моральный климат, копинг-механизмы, варианты психологической защиты, а также персональные данные и индивидуально-психологические особенности каждого члена группы. В целом, результатом психологического воздействия и манипуляция должна стать иная «реальность», в которой формируются новые духовно-нравственные ориентиры и стереотипы поведения.

По мнению Д. Ольшанского движущей силой политического экстремизма стали маргинальные группы и слои.[6] Некоторые исследователи утверждают, что маргиналы ищут «компенсацию» за улично-подъездный образ жизни, вследствие этого ими совершаются общеуголовные и корыстно-насильственные преступления в сфере быта и досуга.[11] Однако у некоторых социальных групп формирование нравственных стереотипов выглядит уязвимо.

В неформальной структуре любой деструктивной и преступной группы особая роль принадлежит ее лидеру. Установлено, что пока есть необходимость, они будут стремиться к воспроизводству, умножению, расширению и продолжению своего дела и самих себя. К. Леонгард отмечает, если различные черты характера и темперамент, формирующие человека, когда он представляет собой отклонение от своего стандарта на лицо, то он может быть причислен к акцентуированному истерическому типу с аномальной способностью к вытеснению. [5]

С целью усиления внушаемости и слепого повиновения лидер использует изоляцию неофитов от бывших друзей и семьи, истощение тела, специальные методы группового давления, управление информацией (манипулирование виной), критическим мышлением, остановка здравого смысла по типу «черно-белое» поощрение зависимости от группы, безысходностью ухода и т.д. Обладает ли лидер группы «харизмой»? По мнению многих авторов, динамическая характеристика лидеров должна включать «базовый образ мышления» с положительной направленностью. Деструктивный лидер не имеет позитивной природы направленности, глубинного мотива любви, защиты, людей.

Соприкосновение молодежи с реальностью проходит сложный путь, в некоторых случаях оно дисгармонично и приводит к ошибке восприятия целостной картины мира. Вариации деструктивного поведения характеризуется полярным заострением/«притуплением» свойств личности, особым реагированием с отклонениями от принятых в социуме поведенческих и моральных норм. Стагнация, внутриличностный конфликт, привнесенные факторы формируют проблемные компоненты направленности в поведении личности. Протестная реакция способна привести молодых людей к социально-психологической девиации (микросоциально-психологической запущенности). Самодеструктивные начала в подростковой и молодежной среде становятся причи- 
ной возникновения информационной «интоксикации», совершению правонарушений и преступлений, наркомании, алкоголизму, аутоагрессии, и т.д.

Молодежь учится понимать сложный мир, однако в отдельных случаях установления психологического контроля с обходом психологической защиты и манипуляцией происходит реформирование сознания, которое резко меняет направленность личности.

В асоциальных объединениях деструктивной направленности используются способы реформирования сознания, такие как провоцирование когнитивного диссонанса, гипнотического транса, внушения, нейролингвистического рефрейминга, информационной перегрузки, сенсорной депривации, нейрологического переимпритинтирования, тоталитарного контроля эмоций, поведения, мыслей и информации.[2] Приписываемое лидерам трансцендентальное начало во многих случаях ошибочное, поскольку авторитета власти и подчинения держится на страхе и подавлении личности. По словам исследователей роль сильных и разнообразных эмоций и поведенческих признаков, жестов и выражений, скрывающих искусный обман и ложь, необходимо разоблачать посредством техники обнаружения, вери- фикации истолкования лжи с соблюдением мер предосторожности. [8]

В настоящее время молодежь имеет возможность ознакомиться с материалами, анализирующих идеологические установки запрещённой на территории Российской Федерации террористической организации «ИГИЛ», психологией «вербовщиков», агитационными материалами. Обеспечение безопасности молодежи от проникновения идеологии терроризма и экстремизма, деструктивных воззрений чуждой идеологии, зависит от совместных усилий органов государственной, исполнительной, законодательной власти, органов местного самоуправления, муниципальных образований, общественных, религиозных и иных организаций.

В целях профилактики импринтной уязвимости, внушаемости, навязываемой реальности требуется комплекс профилактических мер, организация воспитательных и контрпрогандистских мероприятий, мониторинга распознающего настроения, своевременно оказываемой индивидуально-групповой диагностикопрофилактической, психологической и реабилитационной помощи, создающей условия для формирования фрустрационной толерантности.

1. Грановская Р.М. Психология веры. - СПб: Речь, 2004. - 490с.

\section{ЛИТЕРАТУРА}

2. Деструктивные психотехники. Технология изменения сознания в деструктивных культах /под ред. И.Митрофановой. - Электросталь: Эксилибрис, 2002. $-16 \mathrm{c}$.

3. Доценко Е.Л. Манипуляция: психологическое определение понятия. //Психологический журнал. -1993. - Т.14,№ 4. - С.132-138.

4. Криминология /под ред. Ф.Д. Шели. - СПб: Питер, 2003. - 420 с.

5. Леонгард К. Акцентуированные личности. - Ростов-на-Дону: Феникс, 1997. - 71с.

6. Ольшанский Д.Д. Психология терроризма. - СПб.: Питер, 2002. - 175с.

7. Тирских А.А. Преступная идеология: понятие, содержание и меры противодействия // Российский следователь. - 2009. - №3. - С.30-32.

8. Экман П. Психология лжи. - СПб: Питер, 2000. -271с.

9. Юнг К.Г. Аналитическая психология. - СПб: Кентавр, 1994. - 22 с.

10. Злокатов К.В. Деструктивное поведение в различных аспектах его проявления. -URLhttps://cyberleninka.ru/article/n/destruktivnoe-povedenie-vrazlichnyh-kontekstah-ego-proyavleniya/viewer (дата обращения 16.02.2021)

11. Кириллов С.И. Феномен маргинальности и преступное поведение.-URLhttps://cyberleninka.ru/article/n/fenomen-marginalnosti-i-prestupnoe-povedenie/ viewer(датаобращения 16.02.2021)

12. Кравцов Д.Н. Российская молодежь как объект деструктивного воздействия средств идеологического информационно-психологического и культурного противоборства Запада/ Д.Н. Кравцов, В.Д. Исаев, В.Н. Лебедь, К.А. Восканян. -URLhttps://cyberleninka.ru/article/n/rossiyskaya-molodyozh-kak-obektdestruktivnogo-vozdeystviya-sredstv-ideologicheskogo-informatsionno-psihologicheskogo-i-kulturnogo/viewer(дата обращения 16.02.2021) 